\title{
Central Industrial District as an Attempt to Implement the Principles of Sustainable Development in the Inter- War Period Poland
}

\author{
Pawel Grata ${ }^{1}$
}

\begin{abstract}
The interwar Poland was a poorly developed and unevenly developed country. The difference between regions was well to see between well-industrialized and so-called western "Poland A" and backward, agricultural and poor "Poland B" in the east. In the second half of the thirties of the twentieth century, Deputy Prime Minister Eugeniusz Kwiatkowski proposed taking action to eliminate the development differences between individual parts of the country. The government decided to build the Central Industrial District (COP), which was located in backward areas located in the central part of the country. The aim of the project was to implement a number of industrial and infrastructure investments and to make the first step on the way to blur the differences between "Poland A" and "Poland B". Further, the creation of another industrial district east of the COP was assumed. In 1938, E. Kwiatkowski announced the so-called Fifteen-year plan, which was to bring the level of economic development to the level of the entire country until 1954. The large-scale implementation of investment under the COP was interrupted by the outbreak of World War II, but it turned out that the investments undertaken in the second half of the 1930s had a lasting effect. Established in this period, enterprises still play an important role in the economy of present-day south-eastern Poland (Podkarpacie region) and constitute an important element on the way to sustainable development of the country.
\end{abstract}

Keywords: Second Polish Republic, Central Industrial District, state modernization, leveling of development, Eugeniusz Kwiatkowski

\section{Introduction}

Poland in the inter-war period (the Second Polish Republic) was developed insufficiently and unevenly and the division into a relatively well industrialized, so called, Poland A (in the west) and the underdeveloped, agricultural and poor Poland B (in the east) was clearly visible. This situation resulted from the processes taking place in the Polish territory in the $19^{\text {th }}$ century during the national slavery. The lands under the authority of the rapidly developing Germany, i.e., Upper Silesia, Wielkopolska and Danzig Pomerania, actively participated in the modernization processes and were the most advanced parts of Poland. The situation in the remaining parts of the country was much worse. The majority of the lands under the authority of Russia entered the road towards modernization late and the process encompassed only few enclaves, with the Industrial District in Lodz, Dabrowa Basin and Warsaw as frontrunners. The remaining areas were lagging behind. On the lands located east of the Bug River, the industry was almost non-existent and the underdevelopment of agriculture was significant. The commonly observable underdevelopment of Galicia (i.e. the Polish lands under the authority of Austria) could be described in the same way. Apart from few modernity 
centres (with the petroleum industry as a frontrunner), it was underdeveloped, poor and based on fragmented and old-fashioned agriculture (Landau and Tomaszewski, 1991). The restoration of independence in 1918 meant that the new authorities had to merge those extremely diversified areas and offset the differences in the level of the development of the respective regions. The amount of work was enormous, especially when we compare, e.g., the level of the development of highly industrialized and rich Upper Silesia, where the vast majority of people worked in the industry and services, with poor, agricultural eastern areas based on the natural economy. Such drastic differences had a negative impact on the economic structure of the country which was dominated by the agricultural sector in which $60 \%$ of the population found employment. Industry offered employment only to $20 \%$ of people. The urbanization indicator was also low; only $25 \%$ of citizens lived in cities and $75 \%$ in the countryside (in the east it was more than 85\%). Only Bulgaria, Lithuania and Romania were less urbanized than Poland (Brzoza, 2001).

Such great disparities were going to be eliminated thanks to the establishment of the Central Industrial District, the project initiated in 1937 by Eugeniusz Kwiatkowski, the vice prime minister. It was the first step towards the equalisation of standards of living in different parts of the country. The implementation of the project was interrupted by the outbreak of the $2^{\text {nd }}$ World War. However, this initiative must be considered as the first (in the history of Poland), partly successful, attempt to introduce the activities in favour of the sustainable development of the country. This can be confirmed by the pre-war history of the Central Industrial District, the future situation of the areas encompassed by it and a long-term influence of Kwiatkowski's project on the modernization processes taking place in those areas.

\section{The Origin and the Establishment of the Central Industrial District}

Despite the commonly observable disparities, no real actions were taken in order to mitigate them in the first decade of independence. What was understandable, the authorities focused on unifying the Polish lands economically and on strengthening the economic independence of the country. At the beginning of the 20s, the military authorities designated, so called, safety triangle in central Poland, far from the borders with the two most dangerous neighbours, i.e., Soviet Russia and Germany. This move turned out to be extremely important from the point of view of the future changes in the economic policy. Initially, the area was devoted to military investments. However, with time, the authorities understood that the area where the borders of the former Russian and Austrian partitions had crossed, was a good place for industrial investments. What encouraged entrepreneurs was a tax relief introduced in 1928 (Lapa, 2018).

The great economic crisis cancelled the plan of making investments in the safety triangle. However, the course and the seriousness of the economic breakdown forced the authorities to take actions in order to change the economic structure of the country and to offset the differences between respective regions, which were even greater during the crisis. The Four-Year Investment Plan, proclaimed by Eugeniusz Kwiatkowski in 1936, was going to accelerate the modernization processes in the country. However, it quickly turned out that various investments made in different regions of the country did not 
produce any spectacular results (Drozdowski, 1963).

That is why, and also for political and propaganda reasons, Kwiatkowski decided to concentrate investments in a strictly defined area and to initiate the activities in favour of the gradual elimination of the disparities between different parts of the country. At the beginning of 1937, the government made a decision to establish the Central Industrial District which was located in the underdeveloped area of the former safety triangle (region) in the central part of Poland. It encompassed parts of krakowskie, lwowskie, lubelskie and kieleckie voivodships (46 counties), covering the total area of $59900 \mathrm{~km}^{2}$, with nearly 5.7 million people living there. This choice resulted from the strategic (strongly supported by the military circles) as well as economic and socio-demographic reasons. The area of the Central Industrial District was underdeveloped, the urbanization and industrialization level was below the country average (only 17\% of citizens were city dwellers), the agricultural structure was characterised by a high number of fragmented households and the number of people not needed in the countryside (which constituted potential reservoir of free workforce) was estimated to be on the level of 500000 . On the other hand, some raw materials (for the metal and mineral industry), petroleum and natural gas deposits and the potential resources of the unused hydro-energy (important from the point of view of the provision of electric power to the district) could be found there (Jablonowski, 2001).

The aim of the project was, therefore, the realization of many industrial investments, mainly defensive and infrastructural ones, in the underdeveloped region with high unemployment rate and low level of urbanization. The Central Industrial District was divided into three regions: A - raw material base (kieleckie voivodship), B - provision base (lubelskie voivodship) and $\mathrm{C}$ - processing base (lwowskie voivodship and the eastern part of krakowskie voivodship). Importantly, the establishment of the Central Industrial District was the first step towards offsetting the differences between Poland A and B. The next step was the establishment of another industrial district, east of the Central Industrial District, with Lviv in its centre (Golebiowski, 2000).

That way, the Kwiatkowski's project became the first (in the history of Poland) plan which introduced, what we call nowadays, the principles of sustainable development. What is more, in 1938 Kwiatkowski announced the initiation of the Fifteen-Year Plan which would offset the economic differences in the entire country by 1954 . The following three-year periods of its implementation brought further expansion of the defence potential of Poland, the development of communication infrastructure, the improvement of the situation in agriculture, urbanization and further industrialization. It was expected that all those elements would eliminate the existing disparities between different parts of the country in the final phase of the plan (as the result of the outbreak of war only the first part of the plan, for the period of 1939-1942, took an actual form of the legislative act (Landau and Tomaszewski, 1989).

The establishment of the Central Industrial District, which started in 1937, had an extremely fast pace and met with the social enthusiasm which was enhanced by farreaching propaganda. The first results were observed and these were, e.g., the infrastructural investments in the creation of energy and gas networks and in the construction of modern residential areas for workers located in the neighbourhood of factories. The Central Industrial District was dominated by the state endeavours, 
however the private sector also engaged into various investments and its activity was supported by the act on capital allowance passed in April 1938 (Act, 1938). Armament investments were directed at the development of steal and metallurgy industry, weapon and ammunition factories, the production of gunpowder, explosives, chemical products and electrical equipment. The aerospace plants were built and there was also an attempt to create the foundation for the development of automotive industry. Investments in ancillary production (textile, clothing, building and ceramic materials industry) also played an important role. Before the outbreak of the $2^{\text {nd }}$ World War, a few big enterprises (which permanently changed the economy of the region) started to operate. Among them the most important were: Zaklady Poludniowe (steel and machine industry) in a newly built city of Stalowa Wola, Fabryka Obrabiarek in Rzeszow, the aerospace plants in Rzeszow and Mielec and the chemical industry companies in Debica. Many other investments were in the phase of production initiation or at different stages of the construction. The Central Industrial District managed to create about 100000 workplaces (Golebiowski, 2000).

In September 1939, the German aggression interrupted the establishment of the Central Industrial District and it seemed that this would end its existence. However, it did not happen. What is more, the occupying power became the beneficiary of the Kwiatkowski's project due to the fact that it took over the majority of the factories which were further developed. During the occupation they functioned within the German armament complex. That way, the industrial potential (created to strengthen the defensive possibilities of Poland) was used to achieve the opposite goals. However, from the point of view of the continuity of the investments initiated before the war, this meant that the development processes in the region carried on (Wieliczko, 1988).

\section{The Area of the Central Industrial District in the Period of the Real Socialism}

The liberation of the Polish lands caused the destruction of some factories built within the Central Industrial District. However, it also initiated a totally new phase in the history of the region. The communist authorities, who strongly rejected the policy and the achievements of the Second Polish Republic, involuntarily supported the project of Eugeniusz Kwiatkowski (who was no longer allowed to work in the state administration). It was because of the fact that the ideas behind the Central Industrial District, based on the development of heavy industry, including the defence industry, complied with the socialist idea of industrialization implemented in Poland after the war. Therefore, the introduction of the Six-year Plan in 1950 started a new phase in the development of the enterprises established before the war within the Central Industrial District (Grata, 2015). After the change of the Polish borders, which was the consequence of the decisions made during the conference in Yalta, the Central Industrial District was located in the area of krakowskie, kieleckie, lubelskie and, newly established, rzeszowskie voivodship which covered the majority of the processing region. Crucially, despite major investments initiated in the second half of the 30s, their short period of implementation did not allow to make any significant structural transformations in the region. Therefore, after the war, the level of industrialization was still low and the majority of the population still lived in the countryside $(84 \%$ in lubelskie and rzeszowskie voivodships 
and $71 \%$ in kieleckie voivodship, with the national average being on the level of $68 \%$ ). In the situation when the factories built within the Central Industrial District were the only major enterprises in the region (especially in rzeszowskie voivodship), there was a need for further industrial investments based on the foundations set up in the second half of the 30s. Besides, the factories in Rzeszow, Mielec, Debica, Stalowa Wola and Deba became the workplaces for the majority of people living locally during the occupation. Therefore, their quick re-opening was a necessary condition for the reconstruction of a normal economic life (Rocznik, 1947).

This process involved both the reconstruction and launching the production in the destroyed factories as well as the continuation of the investments unfinished before the war. As early as in the $2^{\text {nd }}$ half of the $40 \mathrm{~s}$, the communist authorities made a few endeavours which directly referred to Eugeniusz Kwiatkowski's plan. As the result, the investments initiated before the war were relaunched as early as at the beginning of the 50s, e.g., the chemical plants in Jaslo and Sarzyna, Walcownia Metali Kolorowych in Debica or Fabryka Samochodow Ciezarowych in Lublin (Grata, 2015).

The first years after the war were only the prelude to the further investment expansion in the area of the former Central Industrial District. During the implementation of the SixYear Plan, officially called the Plan of Building the Foundations of Socialism, rzeszowskie and kieleckie voivodships were among the biggest recipients of investment measures. What is more, the industrial plants, built before the war, were quickly expanded, which determined the economic potential of the region. With time, they offered employment to thousands of workers (Kawalec, 1974). Crucially, numerous new enterprises were set up in the region and they were closely linked to the ideas behind the Central Industrial District. Along the development of the industrial potential, there was a rapid expansion of cities and towns associated with it, with Rzeszow, the capital of the new voivodship, as a frontrunner (Rzeszow became a regional political, economic and cultural centre and the number of people living there increased five times between 1944 and 1989) (Bonusiak, 2012).

The above mentioned tendencies characterised the development processes taking place in the area of the former Central Industrial District also in the coming decades of the communist governance in Poland. With the next stages of the investment activity, there happened further development of the pre-war enterprises and the branches of the industry related to them. With time, new elements (which broadened the range of the economic activity of the region) arose, however the image and the economic potential of the region still depended on the factories built at the end of the 30s. Thanks to the financial resources, they were turning into big and relatively modern industrial conglomerates which offered jobs to a great number of people. Huta Stalowa Wola and the aerospace plant in Mielec were the biggest enterprises which offered employment to about 20000 people in the last years of the Polish People's Republic (the aerospace plant in Rzeszow employed several thousand workers at that time). Importantly, the major part of their products was exported, also to the Western countries, and the most popular export products, manufactured in the area of the former Central Industrial District, were: airplanes from Mielec, artillery equipment and construction machines from Stalowa Wola, plane engines and turbochargers from Rzeszow and household appliances produced in Zelmer, the enterprise from Rzeszow which was established after the war 
but which fit into the local industrial traditions (Fiszer and Bluj, 2012; Zelmer, 1986). What confirmed the relevance of the investments initiated within the Central Industrial District, with the aim to mitigate the disparities in the development of the region, were the changes in the employment structure taking place after the war. They were visible especially in the south-east part of the country, i.e. in rzeszowskie voivodship where the former processing region of the Central Industrial District was located (after the administrative reform in 1975, there were four smaller administrative units in the area krosnienskie, przemyskie, rzeszowskie and tarnobrzeskie voivodships). The fastest increase in the employment outside agriculture also happened in this region. From the census in 1931 to 1988, i.e. to the end of the real socialism in Poland, the number of people working outside agriculture in the processing region of the former Central Industrial District increased three and a half times, whereas in the rest of the country two and a half times. Also, the progress in this region was much greater than in the remaining pre-war area of the Central Industrial District. The positive impact of the investment processes initiated by Eugeniusz Kwiatkowski in 1937 was even more visible in the context of the tendencies towards the increase in the employment in the industry in the discussed period. In the entire country it doubled between 1931 and 1988, whereas in the former processing region of the Central Industrial District it increased three and a half times (in the remaining area of the former Central Industrial District the progress was definitely less significant) (Leszczynska, 2018).

Despite those positive tendencies it is worth noticing that, as it had been the case before the war, the investments were unevenly distributed even within the processing region. At the end of the 80s, 90000 people worked in the industry in rzeszowskie voivodship, whereas in przemyskie voivodship (located closest to the eastern border) it was only 27000 (Rocznik, 1988). This reflected the way the investments were located in the interwar period. During that time the eastern counties of the processing region had been neglected in this respect.

\section{The Idea Behind the Industrial District at the Turn of the $20^{\text {th }}$ and $21^{\text {st }}$ Century}

The fall of the communism in Poland created totally new conditions for the functioning of the economy. The former enterprises of the Central Industrial District, which were further developed in the after-war decades, had to face the reality based on the market mechanism. Simultaneously, with the official political "rehabilitation" of the Second Polish Republic, there was a clear comeback to the pre-war ideas, including the economic ideas. The same happened to the project of the Central Industrial District whose traditions clearly revived and which became a fixed element in the economic and political discourse. In the first half of the 90 s, there was even an unsuccessful attempt of its restitution, made by the parliament (Mik, 1995). However, with time, it turned out that the pre-war assumptions and ideas became an important part in the formation of the new economic reality in the south-east area of Poland.

Before that happened, the state enterprises of the former Central Industrial District had to undergo a difficult process of adjustment to the new market conditions and this involved the organizational restructuring, painful reduction in employment (the most difficult situation was in the aerospace plant in Mielec) and the necessity to look for new 
markets, which often required the change in the production profile. They also underwent the ownership transformation which resulted in the majority of them being in the hands of the private sector (national and foreign capital). Only few enterprises from the armament sector (Huta Stalowa Wola, Dezamet Nowa Deba ) remained in the hands of the state. Despite many difficulties, the companies of the former Central Industrial District dealt with a new situation relatively well. They still belonged to the group of the most important economic entities in the region and they continued to play the role of the leaders of the technical and technological progress, setting out the course for the development for the entire processing region of the former Central Industrial District (Grata and Ostasz, 2018).

Under the conditions of the economic transformation, the ideas behind the Central Industrial District remained present not only in efficiently functioning enterprises but also in the broader dimension, proving that the modernization and the pursue to equalise the development disparities still continued in the new reality of the region. This was confirmed by the establishment of special economic zones in the first half of the 90s of the $20^{\text {th }}$ century in the region of the former Central Industrial District. Their aim was to support the development of investments in the areas threatened by unemployment in the period of the economic transformation. The first zone was established in 1995 in Mielec and it directly referred to the pre-war traditions of tax incentives for the entrepreneurs investing in the underdeveloped areas of Poland B. The success of the zone, which with time created over 20000 new workplaces, called for similar actions in other parts of the country. It also became a model of how to solve problems of structural unemployment in the early phase of the transformation in Poland (Jarczewski, 2005).

Another important footprint of the idea behind the Central Industrial District in the reality of the modern economy of Poland was the Association of the Aviation Industry Entrepreneurs “Aviation Valley" established in 2003 in the south-east Poland. It was initiated by the aerospace plant in Rzeszow, which had already been a part of the Pratt\&Whitney group, and which referred to the traditions of the Central Industrial District. The Aviation Valley brings together over 100 entities from the aviation industry and it is one of the most important elements of the modernization processes taking place in the south-east Poland nowadays. It creates a space for a technological transfer, innovation and entrepreneurship in the sector which is associated with modernity. Thanks to the association, which encompasses the former processing region of the Central Industrial District, Podkarpacie, despite still being behind the western part of the country, is more often associated with efficiently prospering aviation companies, rather than the underdevelopment and fragmented farming. Nowadays, its potential can be confirmed by such companies as: Pratt\&Whitney Rzeszow or Sikorsky Aircraft in Mielec. The role of IT companies is also becoming more and more important, with Assecco Poland as a frontrunner. This only proves that the economy of Podkarpacie has an innovative character (Dolina, 2019; Siwak, 2003).

\section{Summary}

Although the implementation of the project was interrupted by the outbreak of the $2^{\text {nd }}$ World War, it turned out that the investments initiated in the second half of the 
30s brought about a permanent effect. The enterprises, established at that time, still play an important role in the economy of the south-east Poland (Podkarpacie region) and are an important element in the sustainable development of the country. In 1938, Eugeniusz Kwiatkowski, the creator of the Central Industrial District, said that it would be built by generations (Drozdowski, 2015) and this turned out to be true, despite the changing socio-economic conditions and systems. The initiative for the sustainable development of Poland, undertaken over 80 years ago, resulted in the significant and visible (in a long run) progress in the area where the investment processes took place. That way, the validity of the idea of the Central Industrial District, introduced between 1937 and 1939, was confirmed.

\section{References}

Bonusiak, W. (2012), Rozwoj demograficzny Rzeszowa w latach 1945-1989, in: W. Bonusiak (ed.), Dzieje Rz̨eszowa. Tom. IV. Rzeszow w latach 1945-1989 (pp. 973-997), Rzeszow: City Hall of Rzeszow.

Brzoza, C. (2001), Polska w crasach niepodleglosci i drugiej wojny swiatowej (1918-1945), Krakow: Fogra.

Dolina Lotnicza, www.dolinalotnicza.pl (2nd April 2019).

Drozdowski, M. M. (1963), Polityka gospodarça rzadu polskiego 1936-1939, Warszawa: PWN.

Drozdowski, M. M. (2015), Historia Centralnego Okeregu Przemyslowego. Geneza - budowa - wizja prayszlosci-opinie, Warszawa - Radom: Wydawnictwo Naukowe ITT-PIB.

Fiszer, M., Bluj, M. (2012), Rz̨eszowska moc. Swiatowy producent silnikow lotniczych WSK Rz̨eszów. Fakty - ludzie mydarzenia, Warszawa: Wydawnictwo Magnum-X.

Golebiowski, J. (2000), COP. Drieje industrializacji w rejonie bezpieczenstwa 1922-1939, Krakow: Wydawnictwo Naukowe Akademii Pedagogicznej w Krakowie.

Grata, P. (2015), Centralny Okereg Przemyslowy [in:] Historia polskich okeregow i regionow przemyslowych, in: L. Dwilewicz, W. Morawski (ed.), Historia polskich okregow i regionow przemyslowych (pp. 75-124), Warszawa: Pracownia Wydawnicza \& Akant.

Grata, P., Ostasz, G. (2018), Losy przedsiebiorstw COP w okeresie transformacji ustrojowej. Wybrane prayklady, in: P. Grata, G. Ostasz, B. Pasterski (ed.), Od projektu do legendy. Centralny Okereg Przemyslowy po osiemdziesieciu latach (1937-2017) (pp. 372-396), Rzeszow: Wydawnictwo Uniwersytetu Rzeszowskiego.

Jablonowski, M. (2001), Wobec zagrozenia wojna. Wojsko a gospodarka Drugiej Rzecaypospolitej w latach 1935-1939, Warszawa: Aspra.

Jarczewski, W. (2005), Kontekst powstania SSE w Mielcu, in: B. Domanski, K. Gwosdz (ed.), Dziesiec lat doswiadczen pierwszej polskiej specjalnej strefy ekonomicznej. Mielec 1995-2005 (pp. 39-46), Mielec: City Hall in Mielec.

Kawalec, W. (1970), Kielecçyzna. Rozwoj gospodarczy regionu, Warszawa: Ludowa Spoldzielnia Wydawnicza.

Landau, Z., Tomaszewski, J., Gospodarka Polski miedzywojennej. Tom IV. Lata interwencjonizmu panstwowego 19361939, Warszawa: Ksiazka i Wiedza.

Landau, Z., Tomaszewski, J. (1991), Gospodarka Polski Ludowej, Warszawa: Krajowa Agencja Wydawnicza.

Leszczynska, C. (2018), Centralny Okereg Przemyslowy a problem dysproporcji cywilizacyjno-gospodarczych miedzy Polska A i B, in: P. Grata, G. Ostasz, B. Pasterski (ed.), Od projektu do legendy. Centralny Okreg Przemyslowy po osiemdziesieciu latach (1937-2017) (pp. 34-60), Rzeszow: Wydawnictwo Uniwersytetu Rzeszowskiego.

Lapa, M. (2018), Idea koncentracji przemyslu w ,trojkacie bezpieczenstwa” i jej realizacja (1921-1936). Preludium do powstania Centralnego Okregu Przemyslowego, in: P. Grata, G. Ostasz, B. Pasterski (ed.), Od projektu do legendy. Centralny Okereg Przemyslowy po osiemdziesieciu latach (1937-2017) (pp. 15-33), Rzeszow: Wydawnictwo Uniwersytetu Rzeszowskiego.

Mik (1995), Bez COP-u, Nowiny, no. 209, p. 1.

Rocznike Statystyczny 1947, (1947), Warszawa: Central Statistical Office of Poland.

Rocznik Statystyczny Wojewodztw (1988), Warszawa: Central Statistical Office of Poland.

Siwak, S. (2003), 1,2 mln zl od Pratta na dobry poczatek. Stowarzyszenie Dolina Lotnicza zainaugurowalo dzialalnosc, Nowiny, no. 187, p. 4 
Act of 9th April 1938 on investment allowence, Journal od Law 1938, no. 26, pos. 404.

Wieliczko, M. (1988), Wojenne losy COP-u, W: A. Chojnowski (ed.), 50 lat Centralnego Okregu Przemyslowego. Materialy z konferencii naukowej, Tarnobreeg 23 I 1988 (pp. 59-76), Warszawa: Stowarzyszenie PAX.

Zelmer: 35 lat 1951-1986, (1986), Rzeszow: Krajowa Agencja Wydawnicza. 